\title{
The Role of Private International Law in Contemporary Society: Global Governance as a Challenge
}

Laura Carballo Piñeiro \& Xandra Kramer*

\section{Introduction}

The private ordering and public regulation of private international law situations has never been an easy task, and it is one to which legislatures generally have not paid a lot of attention. However, our 'open societies'1 do no longer allow for this lack of interest. This is evident from ongoing debates on a range of private international law matters that have attracted attention beyond the originally somewhat secluded private international law scholarship and which regularly receive media attention. These include, for example, private international law questions regarding corporate social responsibility in relation to companies operating in other - developing - countries, the free movement of workers, transnational child abduction, same sex marriages and adoption and surrogate motherhood. The usual conflicts of interests underlying these types of legal relationships and disputes arising from them gain complexity as a result of the transnational dimension and raise pressing questions as to which (domestic) authority ought to address these in a fragmented world with different applicable laws.

An intensely debated public interest case in which jurisdiction and the extraterritorial reach of domestic private law was at stake is the Kiobel v. Royal Dutch Petroleum litigation. ${ }^{2}$ This class suit concerned the question of whether the United States' Alien Tort Statute allows for a cause of action concerning human right violations against Nigerian citizens committed or supported by Dutch, British, and Nigerian oil corporations in the Ogoni Niger River Delta. In short, the US Supreme Court held that there was a presumption against the extraterritorial application of the US Alien Tort Statute and that the present case did not sufficiently 'touch and concern' the territory of the United States. It is needless to say that this rejection of the extraterritorial effect of domestic law and the inherent rejection of jurisdiction

Associate Professor at the Faculty of Law, University of Santiago de Compostela. Professor at Erasmus School of Law, Erasmus University Rotterdam, visiting scholar at Stanford Law School.

1. See further J. Basedow, 'The Law of Open Societies - Private Ordering and Public Regulation of International Relations', 360 R. des C. 9, at 82-133 (2013).

2. Kiobel v. Royal Dutch Petroleum Co., 133 S. CT. 1659 (2013). has a tremendous impact on the possibility to litigate human rights violations in the United States and to get private redress on the basis of tort acts. ${ }^{3}$

Related lawsuits regarding environmental pollution and its effect upon the local environment and citizens have been brought in the Dutch and English courts, taking advantage of the international jurisdiction system established in those countries, ${ }^{4}$ primarily by virtue of the Brussels I Regulation. ${ }^{5}$ While these courts may be willing or are even obliged to accept international jurisdiction, the resolution of these cases may be affected by the application of an apparently innocent conflict rule, generally referring the subject-matter to the lex loci damni, i.e. the law of the place where the damage is sustained as prescribed by the Rome II Regulation. ${ }^{6}$ In fact, in this case the Dutch District Court did accept jurisdiction against the Dutch/English and Nigerian defendants in relation to the environmental damage in Nigeria. ${ }^{7}$ Applying Nigerian law as the law where the damage occurred, the court rejected all claims against the Dutch/English mother company, concluding that the oil spills were the result of sabotage and that - in short - the mother company had not neglegted its duty of care according to Nigerian law. However, it also held that the Nigerian subsidiary was liable for one of the oil

3. See inter alia C.A. Whytock, D.E. Childress III \& M.D. Ramsey, 'Forward: After Kiobel - International Human Rights Litigation in State Courts and under State Law', 3 UC Irvine Law Review 1, at 1-8 (2013); R.P. Alford, 'The Future of Human Rights Litigation after Kiobel, 89 Notre Dame Law Review, at 1749-1772 (2014).

4. A lawsuit undertaken by the Bodo Community v. Shell Petroleum Development Company (Nigeria) Ltd ('SPDC') is pending before the High Court of London. In the Netherlands, judgment has already been delivered by the Hague District Court, see n. 6 and n. 7 and accompanying text.

5. Council Regulation (EC) No. 44/2001 on jurisdiction and the recognition and enforcement of judgments in civil and commercial matters (Brussels I Regulation), as of 10 January 2015 to be replaced by Regulation.

6. See generally Art. 4(1) and - specifically in relation to environmental claims - Art. 7 of Regulation No. 598/2008 on the law applicable to non-contractual obligations (Rome II).

7. In its interim judgment regarding the question of international jurisdiction, the Hague District Court accepted jurisdiction on the basis of Art. 2 Brussels I Regulation, since the first defendant was domiciled in the Netherlands (registered office in London and principal place of business in the Hague) and in relation the second, Nigerian, defendant on the basis of Art. 7 of the Dutch Code of Civil Procedure regarding multiple defendants and related claims; see District Court The Hague (Rechtbank 's-Gravenhage), 30 December 2009, ECLI:NL:RBSGR: 2009:BK8616 and 24 February 2010, ECLI:NL:RBSGR:2010:BM1470. 
spills as it had violated its duty of care to take measures to prevent sabotage. The mother company could not be held accountable for this lack of the daughter company in accordance with Nigerian law. ${ }^{8}$ Though most claims were rejected, the adoption of jurisdiction and the award of damages in relation to one of the claims against the Nigerian Shell subsidiary have been regarded as a breakthrough. This case also lays bare that the approach of a common law country like the United States differs from that of a civil law country like the Netherlands. While in the United States the primary concern seems to be the extraterritorial effect of the law, ${ }^{9}$ the approach of the Dutch was to formally assess its international jurisdiction based upon the applicable jurisdiction rules and, as the second prong of private international law analysis, determine the applicable law upon the conflict rules.

It is against this background that the interconnection of global governance and private international law becomes evident and, thus, the interest in revisiting the foundations of the discipline. One may safely say that never have private international law scholars and practitioners been so closely involved with those focusing on corporate law, human rights and environmental law. At the same time, this example shows that transnational litigation is truly becoming globally connected, or, as it has been labelled in US doctrine, multipolar. ${ }^{10} \mathrm{~A}$ somewhat similar restriction to the extraterritoriality of the US Securities Exchange Act was made in the earlier class action securities case of Morrison v. National Australia already resulted in a draw of cases from the United States to Europe and to Canada. ${ }^{12}$

\section{The Changing Role of Private International Law}

While the political principles dating back to the Treaty of Westphalia established, on the one hand, the correlation between international law and State law and, on the other, the sovereignty principle and that of noninterference in other State's matters, the global society challenges the whole system to the extent that it is transforming the concept of State. ${ }^{13}$

Against this background, the role of private international law in contemporary society is challenged as well. The neutral stance of private international law on governance matters has served the purpose of paying due respect to the said principle of non-interference in other State's matters. ${ }^{14}$ However, the process of globalisation makes clear that 'other State's matters' is a concept that is in a restructuring process itself. The global village generates a market of legal products where individuals and companies may vote with their feet for the law best suited to their interests. Accordingly, pressure is put on States to issue such a law, with the subsequent risk of legislating just to please one party disregarding other members and interests of society. Furthermore, while the interdependence of economies does not allow States to solely follow their own path, migration brings into their core cultures, religions, ethnics and, in the end, values that collide with those of the host State. This development highlights the simple fact that States are not self-contained areas, but that they are closely interrelated, ${ }^{15}$ for which reason the quest for a better global governance has to be on their legislative agenda as a primary goal. That brings private international law and its mediating role to the forefront. Foreign Direct Liability? Exploring the International Relevance of the Dutch Shell Nigeria Case', 10 Utrecht Law Review 1, at 44-54 (2014); A.A.H. van Hoek, 'In de olie. Het proces tegen Shell wegens olielekkages in de Ogonidelta (Nigeria)', 6 Ars Aequi, at $482-90$ (2013).

9. See Kiobel v. Royal Dutch Petroleum (n. 2) and also Morrison v. Australian National Bank, 561 US 247 (2010) and the academic debate on these cases (n. 2 and n. 11). See also Art. 12(b)(6) of the US Federal Rules of Civil Procedure.

10. See M.S. Quintanilla and C.A. Whytock, 'The New Multipolarity in Transnational Litigation: Foreign Courts, Foreign Judgments, and Foreign Law', 18 Southwestern Journal of International Law, at 31-49 (2011), with further references. See also C.A. Whytock, 'Some Cautionary Notes on the "Chevronization" of Transnational Litigation', 1 Stanford Journal of Complex Litigation, at 467-86 (2013).

11. See n. 9. In this case, the US Supreme Court denied the extraterritorial effect of the Securities Exchange Act, limiting securities class actions to US litigants or shares bought on the US stock exchange. See inter alia L.J. Silberman, 'Morrison $v$ National Australia Bank: Implications for Global Securities Class Actions', in D. Fairgrieve and E. Lein (eds.), Extraterritoriality and Collective Redress (2012) $363 \mathrm{ff}$. , and more recently K. Florey, 'Bridging the Divide: The Case for Harmonizing State and Federal Extraterritoriality Principles after Morrison and Kiobel', 27 Global Business and Development Journal 2, at 197-218 (2014); X.E. Kramer, 'Securities Collective Action and Private International Law Issues in Dutch WCAM Settlements: Global Aspirations and Regional Boundaries', 27 Global Business and Development Journal 2, at 235-79 (2014).

2. See W.A. Kaal and R.W. Painter, 'Forum Competition and Choice of Law Competition in Securities Law After Morrison v. National Australia Bank', Minnesota Law Review 133, at 165-85 (2012); Kramer (n. 11), at 236 referring inter alia to two newspaper articles: The Economist, 'Chasseurs d'ambulances: Class-action suits are coming to Europe', 11May 2013 and Het Financieele Dagblad, 'Nederland hoopt stokje VS over te nemen als land van class actions' (by A. de Groot), 17 November 2010 (The Netherlands hopes to take over from the US as the country of class actions). For Canada: T.J. Monestier, 'Is Canada the New Shangri-La of Global Securities Class Actions?', 32 Northwestern Journal of International Law and Business 2, at 305-64 (2012).

13. See R. Michaels, 'Territorial Jurisdiction after Territoriality', in P.J. Slot and M. Bulterman (eds.), Globalisation and Jurisdiction (2004) 105, at 113-15.

14. See Th. Schultz, 'Postulats de justice en droit transnational et raisonnements de droit international prive. Premier balisage d'un champ d'etude', in M. Kohen and D. Bentolila (eds.), Melanges en I'honneur du Professeur Jean-Michel Jacquet (2013) 417, at 418, available at <http://ssrn.com/abstract=2350122>.

15. As shown by the role of comparative law in shaping legal systems, see S.C. Symeonides, Codifying Choice of Law around the World (2014). 


\section{A Civil Law and Common Law Perspective}

Traditionally, and particularly on the European continent, private international law has been viewed primarily as a system of value neutral rules, indicating the applicable law and establishing international jurisdiction. Von Savigny's paradigm of value-neutralism, using objective-geographical connecting factors to designate the most closely connected law, clearly has left its mark on contemporary conflict of laws. Its particular strength may be that private international law operates as a neutral mediator in international disputes where the law, culture and inherent values differ. In a rather formal way, it regulates and coordinates issues of the applicable law and jurisdiction while preserving legal diversity. ${ }^{16}$ The Savignian 'blindfold' does in principle not allow to consider values or policies that underlie the different national laws, apart from a limited application relating to public policy. However, in contemporary society private international law cannot in all instances uphold its position as a impartial intermediary and solely consider geographically oriented connections. It is undeniable that private law also plays a role in effecting policy objectives and in influencing or repudiating behaviour, e.g. fraud, corruption or other tortious conduct. ${ }^{17}$

This point has first been understood in the various common law systems, where there has traditionally been a closer interaction between private international law and public law. This is particularly the case in federal states, such as the United States and Canada where the individual States could never legislate without taking into account that they are part of an international community and thus that there is a public dimension to every private international law situation. However, also in the European Union, where civil law traditions are dominant, private international law is more and more utilised to facilitate policy objectives, with as primary goals to facilitate the proper functioning of the internal market and the protection of certain 'weaker parties' designated by EU law. ${ }^{18}$

16. X.E. Kramer, 'Private International Law Responses to Corruption: Approaches to Jurisdiction and Foreign Judgments and the International Fight against Corruption', International Law and the Fight against Corruption (Advisory Report for the Dutch Royal Society of International Law, No. 139) 99, at 140-41 (2012), available at <http://ssrn.com/ abstract $=2165243>$.

17. Kramer (n. 16), at 141-42. See for an extensive collection of Dutch papers in the area of private law and behaviour, W.H. van Boom, I. Giesen \& A.J. Verheij, Handboek empirie en privaatrecht (2013).

18. See inter alia K. Kreuzer, 'Zu stand und Perspectiven des Europäischen internationalen Privatrechts - Wie europäisch soll da Europäische internationale Privatrecht sein', 70 RabelsZ No. 1, 1 (2006); L.M. van Bochove and X.E. Kramer, 'Opgelegde bescherming in het Europees internationaal privaatrecht: Van waardeneutraal verwijzingssysteem tot communautair beschermingsmechanisme', in F.G.M. Smeele and M.A. Verbrugh (eds.), 'Opgelegde bescherming' in het bedrijfsrecht. Ratio, methodiek en dynamiek van dwingendrechtelijke bescherming van kwetsbare belangen in het bedrijfsrecht (2012), at 5-32, available at <http://papers.ssrn.com/sol3/papers.cfm?abstract_id=1748433>
In the same vein, political considerations of private international law are gaining importance in the academic debate on the coordination of legal systems. ${ }^{19}$ It is undeniable that, after the American conflicts' revolution, the role of values and policies in elaborating conflict rules has been taken for granted. Both American and European approaches were operating on the right assumption that private international law is State law, just as any other field of law, but this also means that values and policies informing conflict rules are purely national, in other words, they pursue national goals. This short-sighted approach was underpinned by the impossible consensus on key values, in particular in the field of family law on which the international debate has mostly focused pursuing the Huntington's theory of a clash of civilisations. ${ }^{20}$ However, post-industrialisation and internationalisation have shifted the focus of this debate, no doubt because of the State's helplessness to impose their policies in this context, making it more urgent to undertake common steps with a view to protecting global commons.

Global commons is a term cherished by public international law referring to resources or areas beyond political power. Engaged authors like Horatia Muir-Watt go beyond this restrictive meaning by focusing on specific interests and rights which must be protected by coordinating States policies, including for example the protection of human rights, labour rights and environmental protection. ${ }^{21}$ The point of departure is the acknowledgement of the WTO's relative success in liberalising the free movement of products, services and capital benefitting international corporations in particular. In fact, how to make corporations accountable is an issue with many ramifications which are to be further explored. Against this background, the role of private international law ought to be reconsidered, more explicitly laying bare the policy considerations, e.g. in addition to favouring the freedoms of movement of products, services, capital and the like, the protection of specific interests and rights need to be more pronounced. In other words, it is time for a more holistic approach.

\section{Contributions to the Present Issue}

The articles included in this issue, dedicated to the role of private international law in contemporary society, dig up the many open debates concerning the challenges of

19. See also on the public-private dimension, A. Mills, The Confluence of Public and Private International Law - Justice, Pluralism and Subsidiarity in the International Constitutional Ordering of Private Law, Cambridge University Press (2009), and A. Mills, 'Rediscovering the public dimension of private international law', 3 Nederlands Internationaal Privaatrecht, at 371-75 (2012).

20. S.P. Huntington, The Clash of Civilizations and the Remaking of the World Order (1996).

21. See further H. Muir-Watt, 'Private international law beyond the schism', 3 Transnational Legal Theory No. 2, 347, at 354 (2011). 
private international law as a governance tool. To kick off, Christopher Whytock's article on 'Faith and Skepticism in PIL: Trust, Governance, Politics, and Foreign Judgments' deals with a baseline of private international law, i.e. tolerance towards the legal divergence to the extent that legal pluralism is taken for granted by private international law. However, the examination of the grounds of refusal for the recognition of foreign judgments laid down by recent legislation in the United States and the EU shows that despite the similarities between both systems, there is room for divergence, which can be traced back to different political approaches. Geert Van Calster also elaborates on those different approaches when addressing 'The Role of PIL in Corporate Social Responsibility' in his contribution. It is clear that while human rights seem a priority of modern societies, there is a clash between the values defended at the home-base country and those practised abroad. In an attempt to fill this gap, resort is made to codes of conduct and tort litigation, but the juridification of the international society is putting too many constraints to aligning the 'global society' with global commons.

As highlighted by Yuko Nishitani, the debate is also intense as regards 'Global citizens and family relations'. However, the open society cannot help but empowering citizens and acknowledge private autonomy as a means to pay due respect to each individual's core values in capital matters such as religion and culture. Multiculturalism is a feature of the open society and as such, it is modifying many assumptions on values and basic standards of conduct. Migration policies involving the political decision of either integrating or assimilating migrants are behind the conflict of laws issue, as well as other ramifications of the need to grant social peace in a given territory such as the one which is pushing States to take into account non-State law as a consequence of legal pluralism arising from migration. Thereby, private international law norms and techniques are being reshaped with a view to reaching a compromise between the different values at stake.

Private international law pays due respect to the policies behind labour and consumer markets as well. While some countries put emphasis on access of individuals to those markets and thus the protective principle is confined to ex-post litigation, others adopt a proactive approach and take advantage of conflict of laws to put workers and consumers on an equal footing with their counterparts. The latter is the case in EU private international law as shown in the contribution by Laura van Bochove on 'Overriding mandatory rules as a vehicle for weaker party protection in European PIL'. For it is not only about implementing a weaker-party-oriented conflict rule but also protecting labour and consumer rights as public commons. In similar terms, Aukje van Hoek addresses the role of private international law in relation to employment law in her article 'PIL: An appropriate means to regulate transnational employment in the EU?' This author highlights the inconsistencies of a factual approach in determining the applicable law to a contract of employment. It makes practitioners draw up a largescale map of the case at hand but in the end, it misses the full picture by not taking into account the collective dimension of labour relations.

To conclude, the contributions in the present issue show that private international law is itself the topic of a vibrant debate which helps to unveil the political considerations underlying human behaviour and thus fine-tune private international law techniques to address particular global governance challenges. Because, as Boaventura de Sousa Santos pointed out, law is not only about normativity, but also 'imagination, representation and description of reality'. ${ }^{22}$
22. See B. de Sousa Santos, 'Law: A Map of Misreading. Toward a Postmodern Conception of Law', 14 Journal of Law and Society 279, at 281(1987). 